\title{
VALUES UNDERLYING PERCEPTIONS OF BREACH OF THE PSYCHOLOGICAL CONTRACT
}

Authors:

Leon Botha ${ }^{1}$

Kgope P. Moalusi

\section{Affiliations:}

${ }^{1}$ South African Police

Services, Pretoria

South Africa

${ }^{2}$ Department of Industrial \& Organisational

Psychology, University of

South Africa, South Africa

\section{Correspondence to:}

Kgope Moalusi

email:

moalukp@unisa.ac.za

Postal address:

Department of Industrial \& Organisational

Psychology, University of South Africa, PO Box 392, UNISA 0003, South Africa

\section{Keywords:}

contract breach, employee expectations; perceptions; psychological contract; values

\section{Dates:}

Received: 18 Feb. 2009

Accepted: 07 July 2010

Published: 11 Oct. 2010

How to cite this article: Botha, L., \& Moalusi, K.P. (2010). Values underlying perceptions of breach of the psychological contract. SA Journal of Industrial Psychology/SA Tydskrif vir Bedryfsielkunde, 36(1), Art. \#817, 12 pages. DOI: 10.4102/sajip.v36i1.817

This article is available at: http://www.sajip.co.za

(C) 2010. The Authors.

Licensee: OpenJournals Publishing. This work is licensed under the Creative Commons Attribution License.

\section{ABSTRACT}

Orientation: This study identifies the most prominent breaches of the psychological contract and the values underlying the perceptions that violations have occurred.

Research purpose: The study identifies the most important breaches and investigates which values underlie employee perceptions of breach of the psychological contract. It also addresses values that lead to employees interpreting incidents as breaches.

Motivation for the study: The study calls on the fact that employees make inconsequential contributions to the terms of many formal employment contracts may imply that such contracts cannot be viewed as documents between equals.

Research design, approach and method: The study identifies the most prominent breaches of the psychological contract and the values underlying the perceptions that violations have occurred.

Main findings: The data revealed lack of promotion, poor interpersonal relations between colleagues and bad treatment by seniors as three main breaches of the contract, and social recognition, world of peace and sense of accomplishment as three dominant values that underlie perceptions of contract violation.

Practical/managerial implications: The competent and intelligent manner in which lack of promotion is handled and communicated to employees is vital because it has implications for their willingness to contribute, their career prospects and their intention to stay in the organisation.

Contribution/value-add: This research can serve as the basis for the development of survey or research instruments that are appropriate and relevant to the population.

\section{INTRODUCTION}

\section{Background to the study}

The employer-employee relationship exists because, at some time, one individual approached another to perform certain tasks and services in exchange for some form of payment. A legal contract of employment amplifies the extent to which this relationship has become formalised. However, formal institutions and procedures are often deficient and ineffective in explaining controversies that continue to beset contemporary employment relationships. Perhaps Guest (1998a, p. 651) is correct in asserting that 'all employment contracts have gaps in them'. Employees make slight and often insignificant contributions to the terms of the formal employment contract (CIPD, 2007). The fact that employees make inconsequential contributions to the terms of many formal employment contracts may imply that such contracts cannot be viewed as documents between equals. (Cullinane \& Dundon, 2006; Guest, 1998a).

The end of the 20th century has witnessed the emergence of the so-called new employment relationship (Baruch, 1999; Grzeda, 1999). The much-discussed turbulent and incessant changes of the 1990s and 2000s with their resultant new modes of organising are said to have further veiled and convoluted employment relationships (Furnham, 2000; Thite, 2001). The new employment relationship, it is argued, has inadvertently and inevitably created feelings of less job security, less organisational attachment, less commitment, less satisfaction and less loyalty among employees (Cooper, 1999; Furnham, 2000). However, Thompson and O'Connell Davidson $(1995$, p. 23) assert that the 'turbulent times has long been part of the (managerial) rhetoric, only since the rise of the mass market has it become the decisive feature of managerial discourse'. Ironically, in this milieu the requisite to remain competitive rests on human capital (CIPD, 2007).

Increased interest in vision and mission statements and values may reveal a desire to capture the hearts and minds of the workforce or to create more inclusive organisations (Parker, 1997). However, Hancock (1997) observes that such inclusive communities are often exclusive of those who do not sing the company song'. This resonates with Cullinane and Dundon's $(2006, \mathrm{p} .123)$ argument that employee expectations are often imposed by corporate values 'partly because management has the power and resources to do so and partly because of wider societal structures and social discourse'.

\section{Trends from the research literature}

Over the years employees' expectations, which can be located in the area of the psychological contract, have become a vital subject of investigation (Guest, 1998a; 1998b; Herriot, Manning \& Kidd, 1997; Rousseau, 1990; Schein, 1978). 
It has been argued that the psychological contract framework enhances our understanding of public sector employees' attitudes and behaviour (Coyle-Shapiro \& Kessler, 2003). We use the psychological contract as a framework to help identify employees' perceptions that the employer has breached the contract.

The psychological contract can be defined as a set of beliefs or perceptions of what one party (the employee or the employer) expects to receive from and is obliged to provide to the other party (Roehling, 1997). It can also be seen as a mental schema or a model of the employment relationship (Rousseau \& Tijoriwala, 1998). The psychological contract is distinct from formal employment contracts/agreements or even implied agreements between the parties, as it is based solely on the perceptions of one party (Roehling, 1997).

A breach or violation of the contract occurs when an employee perceives that the organisation does not deliver on its obligations (Marks, 2001). Morrison and Robinson (1997) define a breach as an affective and emotional experience of disappointment, frustration, anger and resentment that may emanate from an employee's interpretation of the circumstances surrounding a perceived contravention of the contract. It is a calculative assessment of the employment relationship, whereby employees conclude that the organisation did not meet their expectations (Hallier \& James, 1997). The perception of noncompliance or non-reciprocation by the other party is of crucial importance (Hallier \& James, 1997). The principle of reciprocity states that fulfilment of employee obligations is conditional on the organisation fulfilling what employees perceive the organisation to owe them (Herriot et al., 1997).

The psychological contract is based on assumptions of good faith (Rousseau, 1989). Violations are perceived as being serious and may signal a change in the relationship; the relationship is damaged and the employee experiences psychological distress (Rousseau, 1989). Once violation has occurred, the employee will form a different view of the employer and their relationship even if the organisation fulfils the contravened expectation at a later stage (Rousseau, 1989). The extent of the experience of infringement is also influenced by the type of violation, the degree of the discrepancy between the employee's expectations and experienced reality, and whether or not the employee holds the organisation accountable for the breach (McFarlane Shore \& Tetrick, 1995)

Employees react to what they perceive as violation or fulfilment of their psychological contract. Such reactions may impact on organisational indicators such as effectiveness and efficiency (Rousseau, 1989). When the employer fulfils their expectations, employees experience fairness in the employment relationship (Rousseau, 1989) and believe that the organisation values them (Herriot et al., 1997). In addition, reciprocity pressures are created within the employee whereby the employees feel obliged to fulfil their perceived obligations (Coyle-Shapiro \& Kessler, 2003; Herriot et al., 1997; Rousseau, 1989). Fulfilment also leads to less conflict, a stable employment relationship and longer tenure (Rousseau, 1989).

In contrast, when employee expectations are violated, employee attitudes, behaviour and health are affected (Isaksson, 2006). Employees experience feelings of psychological distress, irritation, poorer general health, broken trust, betrayal, deception, injustice, resentment, anger and frustration as well as a decline in life satisfaction, motivation, job satisfaction, organisational commitment, acts of good citizenship behaviour and loyalty (Herriot et al., 1997; Rousseau, 1989). In essence, employees feel that the goodwill in the employment relationship is damaged (Rousseau, 1989). Violation of the psychological contract eventually impacts on organisational performance. Organisations may experience lower performance (Robbins, 1998), increased turnover, employee litigation, unionisation (Rousseau, 1989), absenteeism and accidents (Isaksson, 2006).
The concept of a psychological contract becomes a useful framework for investigating employees' perceptions of the employment relationship because it is concerned with their unspoken expectations and needs that transcend the formal employment contract (Arnold, 1996). These expectations are subjective (Roehling, 1997) and to a large degree based on employee values (Greenhaus, Callanan \& Godschalk, 2000). The content and behavioural consequences of the psychological contract are determined by employee variables such as work values and personal values (Guest, 2004).

Schwartz and Sagiv (1995) define values as desirable goals that may vary in relative importance; that serve as principles to guide a person. Rokeach (1973) says a

value is an enduring belief that a specific mode of conduct or end-state of existence is personally or socially preferable to an opposite or converse mode of conduct or end-state of existence. A value system is an enduring organisation of beliefs concerning preferable modes of conduct or end-states of existence along a continuum of relative importance

(Rokeach, 1973, p. 5)

In the work context, values are defined as a set of attitudes and opinions that are used to evaluate the job, the workplace and the work environment (Pennings, 1970).

Values inhibit or promote the display of role-related and extra-role pro-social behaviours (McNeely \& Meglino, 1992), influence perceptions of breach or fulfilment and provide a framework to interpret events (Greenhaus et al., 2000), implying that a perception of breach and resulting behaviour are guided by values. For the purpose of this investigation, values explain why individuals experience certain events as breaches of the psychological contract.

Various value-based instruments and theoretical frameworks are used in the field of industrial and organisational psychology. The Rokeach Value Survey describes two types of values, namely terminal values, which are desirable end states of existence on one hand, and on the other, instrumental values which are desirable modes of conduct to achieve terminal values (Gregory, 2000, Rokeach, 1973). An individual employs instrumental values to achieve terminal outcomes (goals that the person would like to achieve during his or her life) (Rokeach, 1973). Examples of instrumental and terminal values contained in the Rokeach Value Survey include the following:

\begin{tabular}{ll}
\hline Instrumental values & Terminal values \\
\hline Ambitious (hard-working, aspiring) & Comfortable life (prosperous life) \\
Broad-minded (open-minded) & Exciting life (stimulating, active) \\
Capable (competent, effective) & $\begin{array}{l}\text { Sense of accomplishment (lasting } \\
\text { contribution) }\end{array}$ \\
Cheerful (light-hearted, joyful) & A world at peace (free of war and conflict)
\end{tabular}

Coyle-Shapiro and Kessler (2003) suggest that in instances where public sector employees

share a common set of values with the organisation, they may be more willing to overlook the extent to which their psychological contract has been fulfilled but may be sensitive to feelings that the organisation is supportive

(Kessler, 2003, p. 222)

Based on the foregoing literature, this study explores the most prominent breaches and the values related to perceptions of violation of the psychological contract.

\section{About this study}

The objectives of this study are to identify the most prominent breaches of the psychological contract and to uncover the 
values underlying perceptions that contract violation has occurred among lower level administrative employees in the public sector.

\section{The study addresses two areas of investigation:}

- The first area of investigation: what breaches have occurred? The aim of this question is to identify the most important breaches.

- The second area of investigation: what values underlie employee perceptions of breach of the psychological contract? The values that lead to employees interpreting incidents as breaches are identified.

\section{RESEARCH DESIGN}

\section{Research approach}

This study follows the qualitative tradition because it is suitable for studying complex and subjective phenomena such as employees' perceptions and values, as well as the nuances that emerge during the laddering process. Using Botschen, Thelen and Pieters' (1999) adapted laddering procedure, the participants identified and rank-ordered three violations to their psychological contract. Individual follow-up laddering interviews were conducted. The data were analysed and interpreted using the instrumental and terminal values of the Rokeach Value Survey (Gregory, 2000) and the hierarchical value mapping method (Manyiwa \& Crawford, 2001). This study found 12 values underlying infringement of the psychological contract analogous to the 18 terminal values in the Rokeach Value Survey:

- comfortable life (prosperous life)

- exciting life (stimulating, active)

- a sense of accomplishment (lasting contribution)

- a world at peace (free of war and conflict)

- family security (taking care of loved ones)

- happiness (contentedness)

- inner harmony (freedom from inner conflict)

- mature love (sexual and spiritual intimacy)

- $\quad$ self-respect (self-esteem)

- social recognition (respect, admiration)

- true friendship (close companionship)

- wisdom (a mature understanding of life).

\section{Research strategy}

This research is aimed at investigating individual subjective perceptions and values. The study adopts an interpretative paradigm to allow interaction between the researcher and participants. The aim of the interaction is to allow the researcher to explore individual subjective meanings of psychological contract violations and values which underlie such violations of the contract. How employees come to regard certain incidents and organisational actions as violations of the psychological contract may remain a conjecture, should appropriate and sound methodological frameworks that capture the emerging nuances not be used. How do employees construct the meaning of phenomena such as 'lack of promotions' and 'bad treatment by seniors'? Using hierarchical value mapping, this research is intended to identify the major breaches and the values underlying perceptions of violation of the psychological contract. However, the objective is not to generalise the results to the whole population, but rather to serve as a basis for further exploration.

The ontological assumptions made in this research are that perceptions and values are individual and subjective. The purpose is to explore the perceptions of individual employees without influencing their responses or imposing existing theoretical knowledge on the participants and the discussions.

\section{Research method Research setting}

The research was limited to administrative employees in two head office divisions of a government department in South Africa, for reasons of convenience. For the purpose of this research, 'administrative' refers to employees who are involved in service delivery to clients, provide administrative support such as financial, logistical or general administration, and are appointed in terms of the Public Service Act, Act No. 55 of 1994. This population serves internal customers who have very little contact with external customers such as the public. These two divisions are responsible for administrative functions, including administration of human resources, logistical and financial matters.

\section{Sampling}

The two divisions from which the sample was drawn employ 477 staff members. Each of the two divisions was requested to provide a list of seven potential participants according to the above criteria of administrative employees. The purpose of these criteria was to enhance the homogeneity of the sample. For instance, within the two divisions there are employees who are not employed in terms of the Public Service Act (1994) and the employment conditions, including remuneration, vary. All of the nominees were contacted and requested to attend a briefing session where the purpose of the research was explained and to arrange suitable dates for the laddering procedure. Seven employees elected to participate.

\section{Data collection methods}

The data for both breaches and values were obtained by using Botschen et al.'s (1999) adapted laddering procedure and the laddering interview. Participants produced three ladders individually for each of their three most prominent breaches, ranked in order of seriousness. Each participant was then interviewed in private to confirm the breaches and to clarify the ladders. In some cases, the clarification led to different responses than those that were recorded.

\section{Hierarchical value mapping methodology}

The purpose of hierarchical value mapping (also called the laddering process) is to identify values linked to perceived psychological contract breaches. This process provides insight into human motivation (Gengler, Klenosky \& Mulvey, 1995). In essence, this process provided an indication of why employees experience certain incidents as breaches. Gengler et al. (1995) state that meaning is found in the words that are used to describe attributes, consequences and values, as well as in the connections or relationships between the different concepts or abstractions. The hierarchical value map represents an aggregate cognitive structure which provides information on content/data, structure (patterns of relationships between concepts) and abstractions (values) to derive patterns of meaning (Gengler et al., 1995).

For instance, both parties in the employment relationship have expectations which govern their relationship. Violation of the psychological contract occurs when one party perceives that the other does not deliver on its obligations. For the purpose of this study, a description of a violation experienced such as 'lack of promotions' would reveal the attribute level of the laddering process. The laddering process guides participants through three levels of information gathering and meaning to identify connections between attributes, consequences and values (Botschen et al., 1999):

- The lowest level is the attribute level which represents physical or psychological attributes that can be experienced or observed. One may ask individuals why they prefer employer $\mathrm{X}$ over employer $\mathrm{Y}$. The individuals may respond by describing the attributes of the employer or organisation, such as the fact that the organisation offers flexitime. In 
market research, a good example would be the quality of a product. The breaches experienced by each participant are the attributes for the purposes of this study.

- Consequences are the physiological or psychological outcomes that result from the consumption of products. Attributes are not valued for their own sake but for their capacity to help a person to achieve a desired outcome. Consequences reveal the functional and practical benefits of the attributes (Botschen et al., 1999). It is important to increase our insights concerning an individual's behaviour vis-à-vis quality of a product so that the marketing strategy can be improved. Quality of a product may reveal the affluent status of the consumer. In the context of this study, it is important to transcend recognising the presence of 'bad treatment by seniors' and to understand the outcomes or impact of such treatment on subordinates.

- Values represent the highest level of information. Values are the desired end state of existence such as happiness, security or pleasure. People view attributes as the means to fulfil their values (Divine \& Lepisto, 1998). For example, promotion is perceived as a means through which employees may fulfil their values. However, lack of promotion presupposes that employees' values related to this contract violation may not be fulfilled. For example, lack of promotion was seen to be an impediment to the gratification of the values of social recognition and a sense of accomplishment. In the context of this research, the attributes refer to experiences and incidents of breaches of the psychological contract. Consequences will refer to the effects and interpretation of the experiences and values will represent the respondents' motivations to react or behave negatively in response to perceived breaches.

The laddering method has emerged in the field of psychology and has been extended to other disciplines like marketing and advertising (Botschen et al., 1999; Gengler et al., 1995; Nunkoo \& Ramkissoon, 2009; Veludo-de-Oliveira, Ikeda and Campomar, 2006). Undeniably, marketing and advertising disciplines have adapted the laddering technique to consumer studies and research with great success. Veludo-de-Oliveira et al. (2006, p. 626) say that laddering is appropriate for research 'that elicits hierarchical constructs and can become especially popular in investigating personal values according to the models of the Means-End Chain (MEC) theory'. The initial step in the laddering method attempts to have the participants identify the product attributes. This is followed by the researcher asking the participants about reasons for the choice or preference in step 1 . The researcher continues by asking the participants why the consequence is important to them. Typical questions are "why is that important to you?' This highest level of information represents the values of the participants on the attribute under discussion (Manyiwa \& Crawford, 2001). The attributes, consequences and values are then linked and displayed in a hierarchical value map (Manyiwa \& Crawford, 2001).

The adapted laddering procedure employed by Botschen et al. (1999) is intended to make the laddering exercise manageable. According to this method, participants complete the laddering in a written format. A laddering exercise was demonstrated in the group to allow participants to gain an understanding of the goals and outcomes required of this stage. Each of the participants produced three ladders individually for each of their three most prominent breaches, ranked in order of seriousness. Each participant was then interviewed in privacy to confirm the breaches and to clarify the ladders. In some cases, the clarification led to different responses to those that were recorded. In these instances, the researcher followed the verbal responses rather than the recorded responses.

\section{Recording of data}

All participants' responses and explanations were recorded. The recorded data comprised the researchers' field notes, tape recordings and completed laddering questionnaires.

\section{Data analyses}

Qualitative interpretative methodology was applied to analyse hierarchical value mapping data. The raw data consisted of the researchers' field notes, tape recordings and completed laddering questionnaires. Stenbacka (2001) states that appropriate methodology must be applied to ensure the reliability and validity of a qualitative research. Qualitative research has its own assumptions in terms of theoretical frameworks and these must be consistent with this approach. Methodology is seen as more than methods and may actually reveal the ontological and epistemological stance of the researcher. The preceding statement by Stenbacka (2001) may precipitate questions about reliability and validity and about how the two concepts are applied in qualitative, as against quantitative, studies. However, reference to reliability and validity often stirs fiery debates and controversy in qualitative studies and this study does not pretend to pronounce on this controversy. The debates reveal a lack of homogeneity (perhaps difference) within the qualitative tradition (Golafshani, 2003; Morse, Barrett, Mayan, Olson \& Spiers, 2002; Rolfe, 2006; Winter, 2000). For instance, Morse et al. (2002) vehemently argue that reliability and validity remain appropriate concepts to ensure quality and rigour in qualitative research. Other researchers have generated what they consider to be more appropriate terms for validity in qualitative research. For example, Guba and Lincoln (1981) have proposed four criteria that may be used to evaluate the soundness of qualitative studies.

Improving quality and rigour in qualitative studies means that the research obtains the data it is supposed to gather (Stenbacka, 2001). As Winter (2000) says, the validity of the research hinges on how representative the description is and how justifiable the findings are. Correct sampling procedures, introducing participants to the objectives of the research and the researcher's guidance of the discussion are aimed at dealing with qualitative validity concerns. Data were collected and analysed by the first author. To increase the quality and rigour of this study, the second author immersed himself into the data by reading and re-reading the raw data and by re-examining the first author's preliminary analysis. The final analysis was the outcome of the authors' consensus.

To further enhance the quality of the study, both written and verbal interview data were analysed. Triangulation is viewed as a strategy that includes multiple methods of data collection and analysis and is aimed at improving the quality of the study. This study was based on the qualitative paradigm. The results were based on researcher and participant interaction and intended to elicit subjective employee perceptions from a non-representative sample. Qualitative researchers do not dissociate themselves from the research process. In fact, qualitative researchers embrace their involvement and role within the research. Denying their involvement is viewed as a threat to the quality of the study (Winter, 2000).

All data were considered in relation to recent important events (Cepeda \& Martin, 2000). Social and historical background, such as industrial action and varied conditions of employment, can skew participant and researcher perceptions. In this study, conditions of employment varied. The extent to which the participants are a homogeneous or heterogeneous group may also affect the outcomes of the study. In this study, disparities existed in the employment conditions for people employed in terms of Public Service Act (1994) and those employed in terms of the department's establishment act, the latter being rewarded at a higher level. The other significant point is that the department was undergoing a restructuring process. Veludo-de-Oliveira et al., (2006) recommend that, when using a laddering procedure, the participant group should be sufficiently homogenous and numerous. To ensure a more homogenous participant group, only respondents employed in terms of the Public Service Act (1994) participated in the study. The Act helps to make the sample more homogenous because all the participants are employed under similar conditions of employment. 
Different participants experience the same event in different ways. This did not present a problem for the purpose of this study, as the objective was to capture individual subjective experiences and perceptions. For example, in this study all seven participants perceived lack of promotions as a violation of the psychological contract. However, participants held different views with regard to its significance. Cepeda and Martin (2000) add that a healthy amount of suspicion should be exercised to ensure that participant inputs do not introduce unnecessary or extreme bias or distortion. In this study it is plausible that the seven employees who volunteered to participate had a serious need to voice their 'grievances' with the employer. However, introducing the non-random sample of participants to the objectives of the research and the researcher's guidance of the discussion were aimed at dealing with qualitative validity concerns.

Data analysis proceeded with familiarisation with and immersion in the data by way of reading and re-reading the completed laddering questionnaires and the researcher's field notes, as well as repeatedly listening to the audio tapes. The rationale was to try and identify the views (or concepts) expressed by each participant. These concepts were coded and later identified as an attribute (all contract violations were treated as attributes), consequence or value. Hierarchical value maps were produced, capturing the views of respondents, thereby reflecting the participants' way of thinking with regard to violation of their psychological contract. For the purpose of this study, the three contract violations, namely, 'lack of promotions', 'poor interpersonal relations between colleagues' and 'bad treatment by seniors' represented a description of a violation experienced and therefore would reveal the attribute level of the laddering process.

Qualitative research is concerned with the generalisation of theory/concepts, not generalisations to populations (Hyde, 2000). This study was exploratory and intended to identify and explore the participants' subjective perceptions and values. The participants were not a representative sample of the population or employees of the department concerned. They were seen as individuals who could provide information that could be used for developing meanings and an understanding of the experiences of the individual participants.

The biographical data and data for breaches were tabulated and analysed descriptively. Breaches were treated as attributes and are presented in Table 1. The data for the values were categorised as either consequences or values, depending on the nature of the participants' comments. Attributes, consequences and values were combined to compile hierarchical value maps which are presented in Appendices A to E. An individual hierarchical value map was compiled for each participant. These individual maps presented all three of the breaches, consequences and values for each participant, as well as the interrelationships between the breaches, consequences and values.

The individual maps were consolidated to create a combined hierarchical value map for all of the breaches and values. Appendix A illustrates the hierarchical value map for all reported values and includes single linkages. This hierarchical value map is reproduced without single linkages in Appendix B.

In addition to this, hierarchical value maps were compiled for each of the three prominent breaches. These appear as Appendices C, D and E. The maps were analysed to determine significant relationships between values, and between breaches and values.

\section{FINDINGS}

\section{Breaches}

When participants were asked to identify three violations of the psychological contract and rank them in order of importance, 10 violations were revealed. 'Lack of promotions' was identified
TABLE 1

Identified breaches

\begin{tabular}{|c|c|c|c|}
\hline \multirow{2}{*}{$\begin{array}{l}\text { Breach } \\
\text { Lack of promotions }\end{array}$} & \multirow{2}{*}{$\begin{array}{l}\text { Frequency } \\
7\end{array}$} & \multicolumn{2}{|c|}{ Relative level of importance rating } \\
\hline & & Most important & 5 times \\
\hline & & 2nd most important & 1 time \\
\hline & & 3nd most important & 1 time \\
\hline \multirow{2}{*}{$\begin{array}{l}\text { Poor interpersonal } \\
\text { relations between } \\
\text { colleagues }\end{array}$} & 3 & 2nd most important & 2 times \\
\hline & & 3rd most important & 1 time \\
\hline \multirow[t]{2}{*}{ Bad treatment by seniors } & 3 & 2nd most important & 1 time \\
\hline & & 3rd most important & 2 times \\
\hline $\begin{array}{l}\text { Poor discipline from } \\
\text { employees }\end{array}$ & 2 & 3rd most important & 2 times \\
\hline $\begin{array}{l}\text { Not accommodating } \\
\text { personal issues }\end{array}$ & 1 & Most important & 1 time \\
\hline Poor salary & 1 & Most important & 1 time \\
\hline Bad work environment & 1 & 2nd most important & 1 time \\
\hline $\begin{array}{l}\text { Insufficient housing } \\
\text { subsidy }\end{array}$ & 1 & 2nd most important & 1 time \\
\hline Favouritism & 1 & 2nd most important & 1 time \\
\hline $\begin{array}{l}\text { Lack of development } \\
\text { opportunities }\end{array}$ & 1 & 3rd most important & 1 time \\
\hline
\end{tabular}

by all seven participants as a violation to their psychological contract. The significance of this violation is accentuated by five of the seven respondents perceiving it as most important. Other incidents identified by the participants include poor interpersonal relations between colleagues, bad treatment by seniors and poor discipline from employees. Table 1 indicates the number of psychological contract breaches and their ranking in order of importance. As can be seen from Table 1, the majority of the perceived breaches seemed to reflect employee dissatisfaction with the relational aspects of their psychological contract. The only transactional breaches that were mentioned, poor salary and insufficient housing allowance, were raised by two participants.

\section{Values}

Values data were interpreted by using the terminal values of the Rokeach Value Survey because of the similarity in the definitions of the instrumental and terminal values in the Rokeach survey. It was found that all the values and related responses were logically related to the relevant breaches. For example, the breach of 'bad treatment by seniors' was linked to the values of 'social recognition', 'love', 'exciting life', 'world of peace', 'inner harmony', 'happiness' and 'a sense of accomplishment'.

An individual hierarchical value map was compiled for each participant. Responses that fit into a value definition of the Rokeach Value Survey were classified as values; an example is 'social recognition'. Other responses such as my 'contribution is valued' and 'increased self-worth' were classified as consequences.

Values found in the individual maps were then combined to produce a pooled hierarchical value map for all reported values (Appendix A) to gain a comprehensive overview of the relationships and interrelationships between all psychological contract breaches and values of all participants. Two violations to the contract, namely poor salary and insufficient housing subsidy, were combined into one breach, titled 'poor salary' 
because of the very close correspondence between the two. The resulting hierarchical value map was very complicated and cluttered (see Appendix A). It was necessary to determine cutoff limits for the inclusion of data to find a balance between the inclusion of sufficient detail and the prevention of 'clutter' (Gengler et al., 1995). Appendix B was created, in which all single linkages were removed. In other words, Appendix B contains only linkages that are mentioned more than once. The effect of this is reduced complexity and increased clarity.

Three additional hierarchical value maps were drawn up for the three most common breaches: 'lack of promotions' (Appendix C), 'poor interpersonal relations between colleagues' (Appendix D), and 'bad treatment by seniors' (Appendix E). All of these were explicitly linked to the value of 'social recognition'.

The linkages leading towards a value are called 'hits' and those linkages leading from a value toward another value are called 'exits' for the purpose of this research.

No implication matrix was drawn up because Appendix A provides a graphical overview of the frequency and direction of relationships/linkages (an implication matrix denotes the number of times each element leads to another, or on a hierarchical value map, which element precedes another (Lealo \& De Mello, 2007, p.10)

\section{DISCUSSION}

\section{Breaches}

The psychological contract is a personal and subjective construct, implying that it may be possible for each participant to identify unique and personal breaches. This means that, theoretically, it was possible to have found 21 different breaches between the participants. Table 1 revealed a great deal of consistency and agreement among participants, especially considering that breaches were not discussed between participants; each participant had to individually identify breaches.

A reflection on the assortment of reported contract violations exposes what Guest (1998a) refers to as the agency problem. Guest refers to the different agents who act on behalf of the organisation and may sometimes offer competing contracts. For instance, poor discipline from employees is not directly related to an action of the organisation. It can be clearly seen from the contract breaches identified by the participants in this study that the contracting agents of the organisation include participants' seniors and their fellow employees. Other implied or unspoken agents include those responsible for poor salary, a lack of development opportunities, bad work milieu and favouritism.

The data revealed that participants identified only 10 different breaches. Four of these 10 breaches were raised by two people. These are poor salary, insufficient housing subsidy, favouritism and lack of development opportunities.

The five participants were concerned with only six breaches:

- lack of promotions

- poor interpersonal relations between colleagues

- bad treatment by seniors

- poor discipline from employees

- not accommodating personal issues

- and bad work environment, indicating a high degree of consensus.

Four of the breaches accounted for 15 of the possible 21 nominations. These are, (1) lack of promotions, (2) poor interpersonal relations between colleagues, (3) bad treatment by seniors and (4) poor discipline from employees (refer to Table 1).
For many organisations that seek to become or to remain competitive, the preponderance of the perceived 'lack of promotions' triggers apprehension and disquiet, because the requisite to remain competitive resides with human capital. Organisations are not always able to offer promotions to their employees. However, employees view lack of promotion as a lack of recognition and as receiving no reward for their contributions. Promotion should not always be viewed in monetary terms. The non-economic aspects such as new challenges, roles and assignments may be more alluring to some employees. The competent and intelligent manner in which lack of promotion is handled and communicated to employees is vital because it has implications for their willingness to contribute, their career prospects and their intention to stay in the organisation. As Turnley and Feldman (2000) note:

psychological contract violations are likely to have a pervasive negative impact on employee attitudes and behaviours, including increased neglect of in-role job duties, reduced willingness to engage in voluntary behaviours supportive of the organisation, and increased attempts to leave the organisation altogether.

( Turnley et al. 2000, p. 40)

Research has shown that breach of the psychological contract is, among other things, related to an unwillingness to exert more effort than the minimum required (Herriot et al., 1997), decreased job satisfaction (Linde \& Schalk, 2005), decreased motivation, decreased organisational commitment (Ivanchevich \& Matteson, 2002), increased turnover, increased employee litigation, increased unionisation (Rousseau, 1989) and increased absenteeism (Isaksson, 2006). The principle of reciprocity states that fulfilment of employee obligations is conditional on the organisation fulfilling what employees perceive the organisation to owe them (Herriot et al., 1997).

The effect of 'lack of reciprocity' may mean less pressure from employees to fulfil their obligations towards the organisation. The majority of the perceived psychological contract violations seemed to reflect employee dissatisfaction with what McDonald and Makin (2000) refer to as the relational aspects of their psychological contract. Literature suggests that fulfilment of relational aspects symbolises long-term organisational investments in employees; a relationship is built where the employer fulfils employees' psychological needs in return for services (Herriot et al., 1997). For example, employees expect fairness and equity in the application of personnel procedures such as when employees are promoted. Fulfilment of relational aspects confirms that the organisation values employees and is willing to make long-term commitments (Herriot et al. 1997). The fact that the majority of the psychological contract violations were relational may create doubts about the employer's long-term commitment to invest in employees. The repercussion of the employer's unwillingness to make longterm investment in employees will adversely affect employees' intent to stay with or their loyalty to the organisation, the effort they put into their work and the effort they exert to improve the quality of the services they render. Service organisations are more susceptible to the latter two effects.

The only transactional breaches that were mentioned, poor salary and insufficient housing allowance, were raised by two participants. The transactional aspects of the psychological contract are concerned with short-term quantifiable gains, where the organisation is expected to provide equitable rewards for services rendered (Ivanchevich \& Matteson, 2002). Fulfilment of transactional aspects communicates an organisation's willingness to equitably reward employees for their efforts (McDonald \& Makin, 2000). A perception that the employer violates the transactional facet of the expectations may require a review of the total performance management system. For example, the problems may include a lack of transparency with regard to how performance bonuses are paid, a lack of feedback on why some employees did not receive bonuses and, of course, perceptions of favouritism. 
TABLE 2

Dominant values and participant responses

\begin{tabular}{|c|c|c|}
\hline Social recognition & World of peace & $\begin{array}{l}\text { Sense of accom- } \\
\text { plishment }\end{array}$ \\
\hline -Respect & - Unity & - Fulfil dreams \\
\hline - Social/colleagues & - Show respect & - Do job well \\
\hline - From seniors & - Understanding & - Give all \\
\hline - Status & - Accommodate needs & - Leave a legacy \\
\hline - Recognition & - Show humanity & - Widen horizons \\
\hline - Not rejected & - Team work & - Impact on others \\
\hline -Acceptance & - Trust one another & - Help others \\
\hline - Social interaction & - Sharing & - Set an example \\
\hline - Promotion & - Loyalty & - Success \\
\hline - Other look up & - Acceptance & - Learn \\
\hline - Be appreciated & - Openness & - Inspire others \\
\hline - Not just a number & - Get along & - Pride in work \\
\hline - Mutual respect & - Family relationships & - Have a purpose \\
\hline - Dignity & - Better society & $\begin{array}{l}\text { - Set example to } \\
\text { children }\end{array}$ \\
\hline - Contribution is valued & - Socialise & - Cannot just exist \\
\hline - Recognition of effort & - Order & $\begin{array}{l}\text { - Life is gift, you have } \\
\text { one chance }\end{array}$ \\
\hline - Not only here to do work & - Routine & - Impact on the world \\
\hline \multirow[t]{9}{*}{ - Not only a number, is noticed } & - No uncertainty & $\begin{array}{l}\text {-Accomplishment and } \\
\text { growth }\end{array}$ \\
\hline & - Good work environment & - Work is up to date \\
\hline & $\begin{array}{l}\text { - Be who you are, personality } \\
\text { stays the same }\end{array}$ & $\begin{array}{l}\text {-Achieve career } \\
\text { development goals }\end{array}$ \\
\hline & $\begin{array}{l}\text { - Positive relationships } \\
\text { generates positive reactions }\end{array}$ & $\begin{array}{l}\text { - Know where you are } \\
\text { going }\end{array}$ \\
\hline & $\begin{array}{l}\text { - Treat others as you want to } \\
\text { be treated }\end{array}$ & $\begin{array}{l}\text { - Enjoy } \\
\text { accomplishments }\end{array}$ \\
\hline & $\begin{array}{l}\text { - Pleasant interpersonal } \\
\text { relationships }\end{array}$ & $\begin{array}{l}\text { - Do something of } \\
\text { value }\end{array}$ \\
\hline & - Pleasant work environment & - Contribute to society \\
\hline & - Good family relationships & - Fulfil a purpose in life \\
\hline & & $\begin{array}{l}\text { - Reason to wake up, } \\
\text { be motivated }\end{array}$ \\
\hline
\end{tabular}

The most common breach of contract was the perceived lack of promotion, followed by poor interpersonal relations between colleagues and bad treatment by seniors.

\section{Values}

The purpose of laddering was to identify the values linked to perceived breaches. In essence, this process provided an indication of why participants experienced certain incidents as breaches. The combined hierarchical value maps (Appendices $\mathrm{A}$ and $\mathrm{B})$ provided an overview of participant values relating to breaches.

Table 2 lists the participant responses related to each of the three dominant values: social recognition, a sense of accomplishment and a world of peace.

In summary, breaches arose because of a perceived lack of recognition of employees' value and of them as persons. In addition, employees seemed to perceive that their work did not provide them with the satisfaction and growth that they needed. Participants were also dissatisfied with the work climate and with their relationships with colleagues.

It is noticeable that in general, individual participants related all three of their prime breaches of the contract to the same core values. This means that one or two values were central to an individual's assessment of all the recorded breaches. There was a high level of agreement between the participants on which values were involved in perceptions of breach (see Appendices A and B). These were the values with the largest number of hits and exits. Appendix A was used to determine the number of hits and exits of each value. The values of social recognition, a world of peace, and sense of accomplishment, received the largest proportion of all hits. This means these are the predominating values and ipso facto the prevailing attitude and behaviour.

'Social recognition' had the highest number of hits (23). Three hits originated directly from the breach of 'lack of promotion', two from 'poor interpersonal relationship' and another three from 'bad treatment by seniors'. 'The need for recognition' appeared to be compromised by a lack of promotion. Participants perceived that the organisation did little to acknowledge their contributions and to reward them according to their expectations. Recognition in the workplace can be afforded in the form of public recognition, for example, a simple thank you or congratulations, or even broadcasting the accomplishment on the company notice board or in other media.

Social recognition had 16 exits, seven towards 'a sense of accomplishment'. The participants expressed a great need for recognition of their efforts/work and of them as persons. It was evident that the participants viewed organisational recognition, in particular, as an indicator of accomplishment/ achievement in life.

'Social recognition' was also closely related to 'inner harmony' (three exits) and three returned from 'inner harmony'. Recognition, then, contributed to an experience of harmony and a sense of harmony was indicative of social recognition.

Impeding social recognition fulfilment may have sombre consequences, especially for service and public sector organisations. Employees want to be recognised and appreciated for their expertise and contributions toward the goals of the organisation. The participants indicated a need for respect from colleagues and supervisors, being appreciated and recognised as a person and for their contributions to the organisation. Perhaps this is indicative of the fact that for most public servants, the reward of social worth is a stronger driver than economic gain. As Coyle-Shapiro and Kessler (2003) put it:

acknowledgement of the employees' worth by the employing organisation is likely to be viewed as particularly important to public servants. If an employee's own employer fails to recognise such worth, then what chance is there that the rest of society will?

(Kessler, 2003, p. 23)

It can be deduced from observations made in this study that the need for recognition is vital to individual employees. Supervisors or managers may need to understand the importance of giving praise and encouragement to their subordinates. Perhaps they need to consider that their subordinates view recognition seriously. Social recognition is a small but significant gesture that may go a long way towards making an organisation more humane and functional.

'A world of peace' scored 13 hits, four from 'a sense of accomplishment', three from 'social recognition' and two from 'inner harmony'. It had nine exits, five to 'social recognition'. The values of 'social recognition' and 'world of peace' appeared supportive of each other. One expressed a need for recognition as a person and the other, a need for closer teamwork and equality. This was supported by the participants' expressed need for unity, understanding, trust, order and a generally pleasant work environment.

The close relationship with 'a sense of accomplishment' indicated that experiences of personal and career accomplishment may contribute to better relationships at work and at home. This was supported by the strong relationship with 'friendship' (four exits).

The value of 'sense of accomplishment' scored 17 hits. 'Social recognition' contributed seven hits and 'inner harmony' contributed three. The participants appeared to equate an experience of accomplishment with recognition from co-workers and the organisation or supervisors. Two hits 
originated directly from the breach 'lack of promotions'. Four of the nine exits from this value exited towards 'a world of peace'. It was concluded that the participants strongly related accomplishment as a person with experiencing a peaceful environment, especially at work. This value was commonly identified at a stage when the participants exhausted their feedback at the termination of the laddering interview. This could indicate this as one of the highest levels of values. Work is a major life role, and a perception of a lack of a sense of accomplishment deprives a person of finding fulfilment in that role (Greenhaus et al., 2000). The prominence of the breach of 'lack of promotions' and the value of 'social recognition' pointed to a frustrated need to achieve and do something of value in life.

'Sense of accomplishment' was also found to be related to 'inner harmony', suggesting that a lack in one would have an effect on the other. If people's sense of accomplishment in their work is frustrated, their inner harmony may be disturbed. For example, impeding the employees' need to grow and leave a legacy may trigger feelings of an unbalanced life and induce stress. Employees may also move on in search of better opportunities elsewhere. Specific responses associated with a sense of accomplishment included 'fulfilling your dreams', 'leaving a legacy', 'having a purpose' and 'growth'. Some of the responses expressive of inner harmony include 'balanced life' and 'stress-free'.

\section{Values related to the most prominent breaches}

Three additional hierarchical value maps were drawn up for the three most common breaches: 'lack of promotions' (Appendix C), 'poor interpersonal relations between colleagues' (Appendix D) and 'bad treatment by seniors' (Appendix E). All of these were explicitly linked to the value of 'social recognition'.

The hierarchical value map for the most common breach, 'lack of promotion' (Appendix C) revealed that the participants viewed promotion primarily as a recognition of their efforts. Specific comments included 'having others look up to you', 'recognition of effort', 'appreciation and respect'. It was evident that the participants viewed promotions as an indication of organisational recognition of their efforts. In the main, promotions are not about exorbitant salary hikes or fancy job titles. Employees want new responsibilities, opportunities to use their skills, praise, and acknowledgement that they are valued and appreciated.

Employers may consider the significance of perceptions, and work to circumvent perceptions and feelings that employees are not valued. Employers can be more transparent and less secretive and communicate as far as promotions are concerned. The social value ('recognition') and the instrumental value ('family security') of promotion pointed to a need to accomplish something of value in life. In turn, recognition was strongly related to 'a sense of accomplishment' (five exits). The responses included 'leaving a legacy', 'growing as a person' and 'doing something of value'. These responses attest to the significance of new assignments and responsibilities and opportunities to use one's skills.

Only a few comments and values were related to transactional needs such as financial advancement and taking care of basic needs. It should be kept in mind that the participants may have tried to portray a socially desirable picture by avoiding comments that stressed financial gain.

The breach of 'poor interpersonal relations between colleagues' (Appendix D) revealed that the participants experienced a violation of their need for a world of peace. Issues such as openness, trust, and pleasant work and family relations were raised. The value of 'social recognition' also appeared to be violated when this breach occurred. This value received two direct hits from the breach of 'poor interpersonal relations between colleagues' and four from the value 'a world of peace'. The participants expressed a need for respect and acceptance among colleagues. It was also reported that the value of 'inner harmony' was compromised, especially by interpersonal stress at work.

Interpersonal relations also relate to social recognition because both have to do with affirming another person's value and therefore trust between them. Employees spent a great deal of their time in work organisations. Therefore, the social aspect of the workplace should not be a source of stress. Workplaces comprise diverse people. Prejudice, stereotypes and simple misconceptions often exacerbate bad interpersonal relations. Diversity management programmes may be used to circumvent misapprehension and false impressions that people develop about others. Some organisations take the initiative to ensure that employees come to appreciate the richness and varying perspectives that diversity may offer them. As reported elsewhere in this study, poor discipline from employees and poor interpersonal relations are not directly related to an action of the organisation. This issue of the contracting agency requires organisational attention. The breach of 'bad treatment by seniors' (Appendix E) was strongly related to a perceived lack of respect, recognition and acceptance by supervisors. The other reported values did not feature as strongly. The only other noticeable relationship was the mutual interaction between the values of 'friendship' and 'a world of peace'. This relationship highlighted the need for humanity, friendship and needing one another. There appeared to be an expectation that the organisation should take responsibility for the social environment at work.

The other prominent violation was the absence of peaceful relationships at work ('a world of peace'). These three hierarchical value maps again confirmed the prominence of the values of 'social recognition', 'a world of peace' and 'sense of accomplishment'. The value most prominently violated was that of 'social recognition'.

The participants displayed general consensus on what breaches they had experienced and what values were relevant when violations were experienced. Different cultures identified different breaches but displayed a high level of value consensus (Schwartz \& Sagie, 2000; Schwartz, Melech, Lehman, Burgess, Harris \& Owens, 2001). This could indicate that the underlying motivations of why the participants experienced incidents as breaches were similar. The identified values provided an indication of why the participants experienced certain incidents as breaches. The resulting behaviour based on frustration of values was not investigated.

\section{Conclusions}

Despite all the criticism relating to the concept of the psychological contract, it does provide an expedient framework in helping us to understand the subjective perceptions of employees. The psychological contract of the employee is based on unspoken needs and expectations that fall outside formalised employment agreements (Roehling, 1997). If the employer satisfies the employees' expectations, they will feel obligated to reciprocate by adhering to their responsibilities (Herriot et al., 1997; Robinson \& Morrison, 1995; Rousseau, 1998). Violations or perceived violations of employees' psychological contracts lead to a breakdown of the employer/employee relationship and to employees justifying undesirable or negative behaviour (Herriot et al., 1997; Rousseau, 1998).

Employees expressed values that convey a need for growth, doing something of value, fulfilling a purpose, lack of respect, not simply being a number, acceptance and appreciation. It was stated that values are used to assess an individual's experiences (Elizur, 1996; Greenhaus et al., 2000;) and eventual reaction to that stimulus (McNeely \& Meglino, 1992).The identified 
values can then be viewed as an indication of why participants experience certain incidents as breaches.

The most prominent frustrated value is the need for social recognition. The most prominent themes under this value were a lack of respect and recognition for efforts at work. Another prominent frustrated value was a sense of accomplishment which seemed to be dependent on the level of social recognition that employees experienced; the lack of recognition led to a frustrated sense of accomplishment.

\section{Limitations}

The results are not to be interpreted as the results of a survey where the perceptions of a representative group are obtained and generalised to the whole population. The sample size was limited due to the exploratory nature of the research. The sample may also be biased, because the participants were self-selected (they volunteered). The participants might have seen their participation as on opportunity to express their dissatisfactions with the employer. This research can, for example, serve as the basis for the development of survey or research instruments that are appropriate and relevant to the population.

\section{REFERENCES}

Arnold, J. (1996). The psychological contract: A concept in need of closer scrutiny? European Journal of Work and Organisational Psychology, 5(4), 511-520.

Baruch, Y. (1999). Integrated career systems for the 2000s. International Journal of Manpower, 20(7), 432-457.

Botschen, G., Thelen, E.M., \& Pieters, R. (1999). Using meansend structures for benefit segmentation. European Journal of Marketing, 33(1/2), 33-58.

Cepeda, G., \& Martin, D. (2005). A review of case studies publishing in Management Decision: Guidelines and criteria for achieving quality in qualitative research. Management Decision, 43(6), 851-876.

CIPD. (2007). Managing change: The role of the psychological contract, pp. 1-13. Retrieved February 14, 2007, from http:// www.cipd.co.uk.

Cooper, C.L. (1999). Can we live with the changing nature of work? Journal of Managerial Psychology, 14(7/8), 569-572.

Coyle-Shapiro, J.A.M., \& Kessler, I. (2003). The employment relationship in the U.K. public sector: A psychological contract perspective. Journal of Public Administration Research and Theory, 13(2), 213-230.

Cullinane, N., \& Dundon, T. (2006). The psychological contract: A critical review. International Journal of Management Reviews, $8(2), 113-129$

Denzin, N.K., \& Lincoln, Y.S. (2000). Introduction: the discipline and practice of qualitative research. In Denzin, \& Lincoln (Eds), Qualitative research (2nd edn., pp. 1-46). Thousand Oaks: Sage.

Divine, R.L., \& Lepisto, L. (1998). A means-end analysis of linkages between bank attributes and consumer values: a correlational approach. The Journal of Marketing Management, $8(1), 72-79$.

Elizur, D. (1996). Work values and commitment. International Journal of Manpower, 17(3), 25-30.

Furnham, A. (2000). Prognostications about the world of work 20 years into the millennium. Journal of Managerial Psychology, 15(3), 242-254.

Gengler, C.E., Klenosky, D.B. \& Mulvey, M.S. (1995). Improving the graphic representation of means-end results. International Journal of Research in Marketing, 12, 245-256.

Golafshani, N. (2003). Understanding reliability and validity in qualitative research. The Qualitative Report, 8(4), 597-607.

Greenhaus, J., Callanan, G. \& Godschalk, V.M. (2000). Career management. Fort Worth: Dryden.

Gregory, R.J. (2000). Psychological testing: history, principles and applications (3rd edn.). Boston: Allyn \& Bacon.

Grzeda, M.M. (1999). Re-conceptualising career change: A career development perspective. Career Development International, 4(6), 305-311.
Guest, D.E. (1998a). Is the psychological contract worth taking seriously? Journal of Organisational Behaviour, 19, 649-664.

Guest, D.E. (1998b). On meaning, metaphor and the psychological contract. Journal of Organisational Behaviour, 19, 673-677.

Guest, D.E. (2004). The psychology of the employment relationship: an analysis based on the psychological contract. Applied Psychology: An International Review, 53(4), 541-555.

Hallier, J., \& James, P. (1997). Management enforced job change and employee perceptions of the psychological contract. Employee Relations, 19(2), 222-247.

Hancock, P.G. (1997). Citizenship or vassalage? Organisational membership in the age of unreason. Organization, 4(1), 93111.

Herriot, P., Manning, W.E.G., \& Kidd, J.M. (1997). The content of the psychological contract. British Academy of Management, 8, 151-162.

Hyde, K.F. (2000). Recognising deductive processes in qualitative research. Qualitative Market Research: An International Journal, 3(2), 82-90.

Isaksson, K. (2006). Psychological contracts across employment situations (PSYCONES). Stockholm: National Institute for Working Life (Arbetslivsinstitutet).

Ivanchevich, J.M., \& Matteson, M.T. (2002). Organisational behaviour and management. Boston: McGraw Hill.

Leão de Souza, A.L.M., \& De Mello, S.C.B. (2007). The meansend approach to understanding customer values of a online newspaper. Brazilian Administration Review, 4(1), 1-20.

Linde, B.J., \& Schalk, M.J.D. (2005). The influence of prior employment relations on the experience of the psychological contract: A South African case study. Paper presented at the 2005 HR Conference on Prior Relationship and the Psychological Contract, Enschede.

Manyiwa, S., \& Crawford, I. (2001). Determining linkages between consumer choices in a social context and the consumer's values: A means-end approach. Journal of Consumer Behaviour, 2(1), 54-70.

Marks, A. (2001). Developing multiple foci conceptualisation of the psychological contract. Employee Relations, 23(5), 454-469.

McDonald, D.J., \& Makin, P.J. (2000). The psychological contract, organisational commitment and job satisfaction of temporary staff. Leadership and Organisational Development Journal, 21(2), 84-91.

McFarlane Shore, L., \& Tetrick, L.E. (1995). The psychological contract as an explanatory framework in the employment relationship. In C.L. Cooper \& D.M. Rosseau (Eds.). Trends in organistational behaviour (Vol 1). Chichester, West Sussex: Wiley.

McNeely, B.L., \& Meglino, B.M. (1992, August). Good soldiers or good duty? The role of work values and contextual antecedents in prosocial organisational behaviour. Paper presented at the Academy of Management, Las Vegas.

Morrison, E.W., \& Robinson, S.L. (1997). When employees feel betrayed: A model of how psychological contract violation develops. Academy of Management Review, 22(1), 226-256.

Morse, J.M. (Ed.) (1991). Qualitative nursing research: A contemporary dialogue. Newbury Park: Sage.

Morse, J.M., Barrett, M., Mayan, M., Olson, K., \& Spiers, J. (2002). Verification strategies for establishing reliability and validity in qualitative research. International Journal of Qualitative Methods, 1(2), 13-22.

Nunkoo, R., \& Ramkissoon, H. (2009). Applying the means-end chain theory and the laddering technique to the study of host attitudes to tourism. Journal of Sustainable Tourism, 17(3), 337-355.

Parker, M. (1997). Organizations and citizenship. Organization, 4(1), 75-92.

Pennings, J.M. (1970). Work-value systems of white-collar workers. Administrative Science Quarterly, 15, 397-405.

Public Service Act, No 103 (1994). Government Gazette. (Vol. 3, No. 15791).

Robbins, S.P. (1996). Organizational behaviour: concepts, applications and controversies (7th edn.). Englewood Cliffs: Prentice Hall. 
Robbins, S.P. (1998). Organizational behaviour: Concepts, applications and controversies (8th edn.). Upper Saddle River: Simon \& Schuster.

Robinson, S.L., \& Morrison, E.W. (1995). Psychological contracts and OCB: the effect of unfulfilled obligations on civic virtue behaviour. Journal of Organisational Behaviour, 16, 289-298.

Roehling, M.V. (1997). The origins and early development of the psychological contract construct. Journal of Management History, 3(2), 204-207.

Rolfe, G. (2006). Validity, trustworthiness and rigour: Quality and the idea of qualitative research. Journal of Advanced Nursing, 53(3), 304-310.

Rokeach, M. (1973). The nature of human values. New York: The Free Press.

Rousseau, D.M. (1989). Psychological contracts in organisations. Employee Responsibilities and Rights Journal, 2(2), 121139.

Rousseau, D.M. (1990). New hire perceptions of their own and their employer's obligations: A study of psychological contracts. Journal of Organisational Behaviour, 11, 389400.

Rousseau, D.M. (1998). The 'problem' of the psychological contract considered. Journal of Organisational Behaviour, 19, 665-671.

Rousseau, D.M., \& Robinson, S.L. (1994). Violating the psychological contract: Not the exception but the norm. Journal of Organisational Behaviour, 15, 245259.

Rousseau, D.M., \& Tijoriwala, S.A. (1998). Assessing psychological contracts: Issues, alternatives and measures. Journal of Organisational Behaviour, 19, 679-695.

Schein, E.H. (1978). Career dynamics: Matching organisational and individual needs. Reading: Addison Wesley.

Schreuder, A.M.G. \& Theron, A.L. (1997). Careers: an organisational perspective. Kenwyn: Juta.
Schwartz, S.H., Melech, G., Lehman, A., Burgess, S., Harris, M., \& Owens, V. (2001). Extending the cross-cultural validity of the theory of basic human values with a different method of measurement. Journal of Cross-Cultural Psychology, 32(5), 519-542.

Schwartz, S.H., \& Sagie, G. (2000). Value consensus and importance. Journal of Cross-Cultural Psychology, 31(4), 465497.

Schwartz, S.H., \& Sagiv, L. (1995). Identifying culture specifics in the content and structure of values. Journal of CrossCultural Psychology, 26(1), 92-116.

Sobal, J. (2001). Sample extensiveness in qualitative nutrition education research. Journal of Nutrition Education, 33(4), 184-192.

Stenbacka, C. (2001). Qualitative research needs quality concepts of its own. Management Decision, 39(7), 551-556.

Terre Blanche, M., \& Durrheim, K. (1999). Research in practice: Applied methods for the social sciences. Cape Town: UCT Press.

Thite, M. (2001). Help us but help yourself: The paradox of contemporary career management. Career Development International, 6(6), 312-317.

Thompson, P., \& O'Connell Davidson, J. (1995). The continuity of discontinuity: Managerial rhetoric in turbulent times. Personnel Review, 24(4), 17-33.

Turnley, W.H., \& Feldman, D.C. (2000). Re-examining the effects of psychological contract violations: Unmet expectations and job dissatisfaction as mediators. Journal of Organisational Behaviour, 21(1), 25-42.

Veludo-de-Oliveira, T.M., Ikeda, A.A., \& Campomar, M.C. (2006). Discussing laddering application by the means-end chain theory. The Qualitative Report, 11(4), 626-642.

Winter, G. (2000). A comparative discussion of the notion of validity in qualitative and quantitative research. The Qualitative Report, 4(3\&4). Retrieved February 25, 1998, from http://nova.edu/ssss/QR/QR4-3/winter.html.

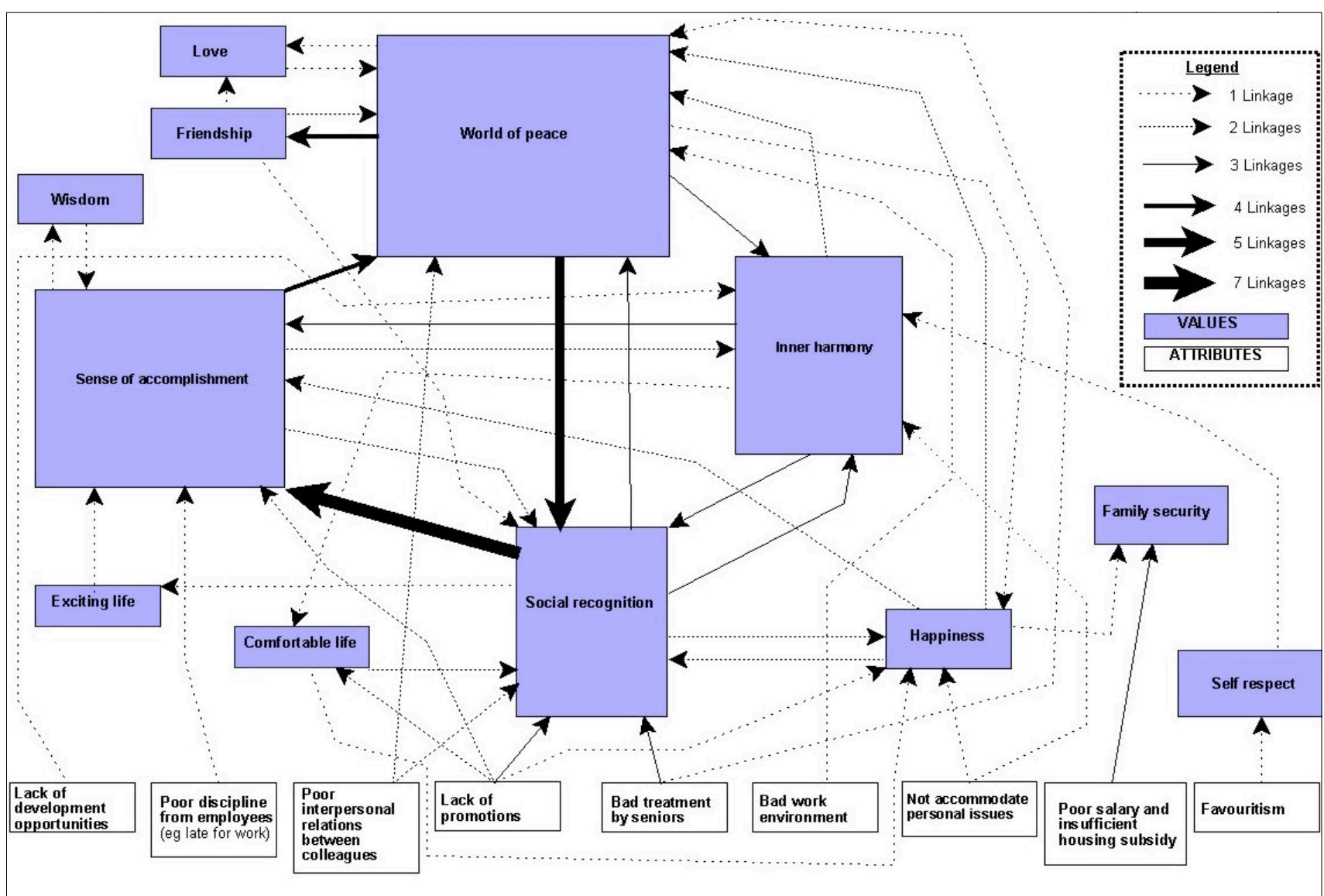

APPENDIX A

Hierarchical value map for all reported values - Including single linkages 


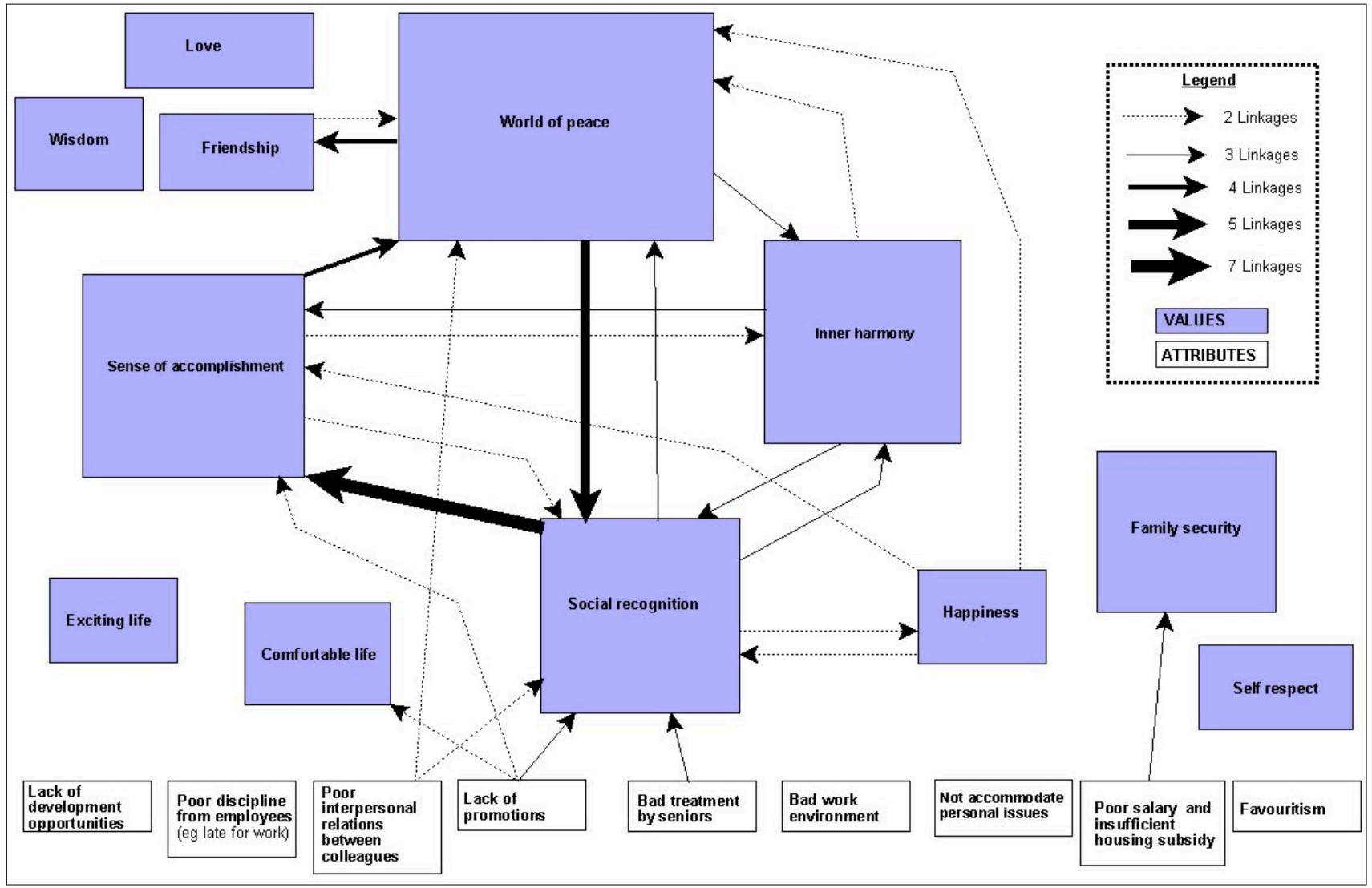

APPENDIX B

Hierarchical value map for all reported values - Excluding single linkages

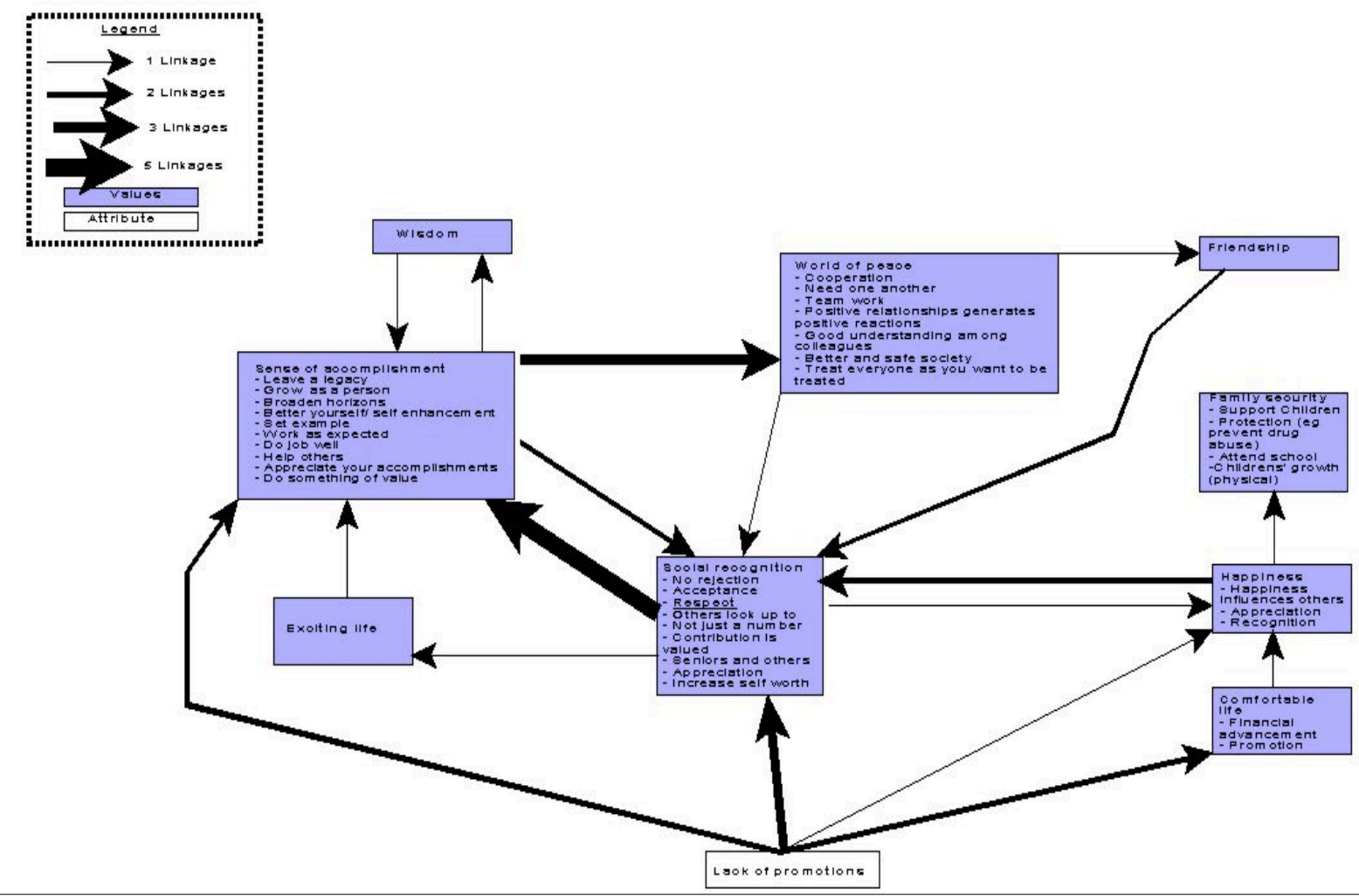

APPENDIX C

Hierarchical value map for values linked to 'Lack of promotions' 


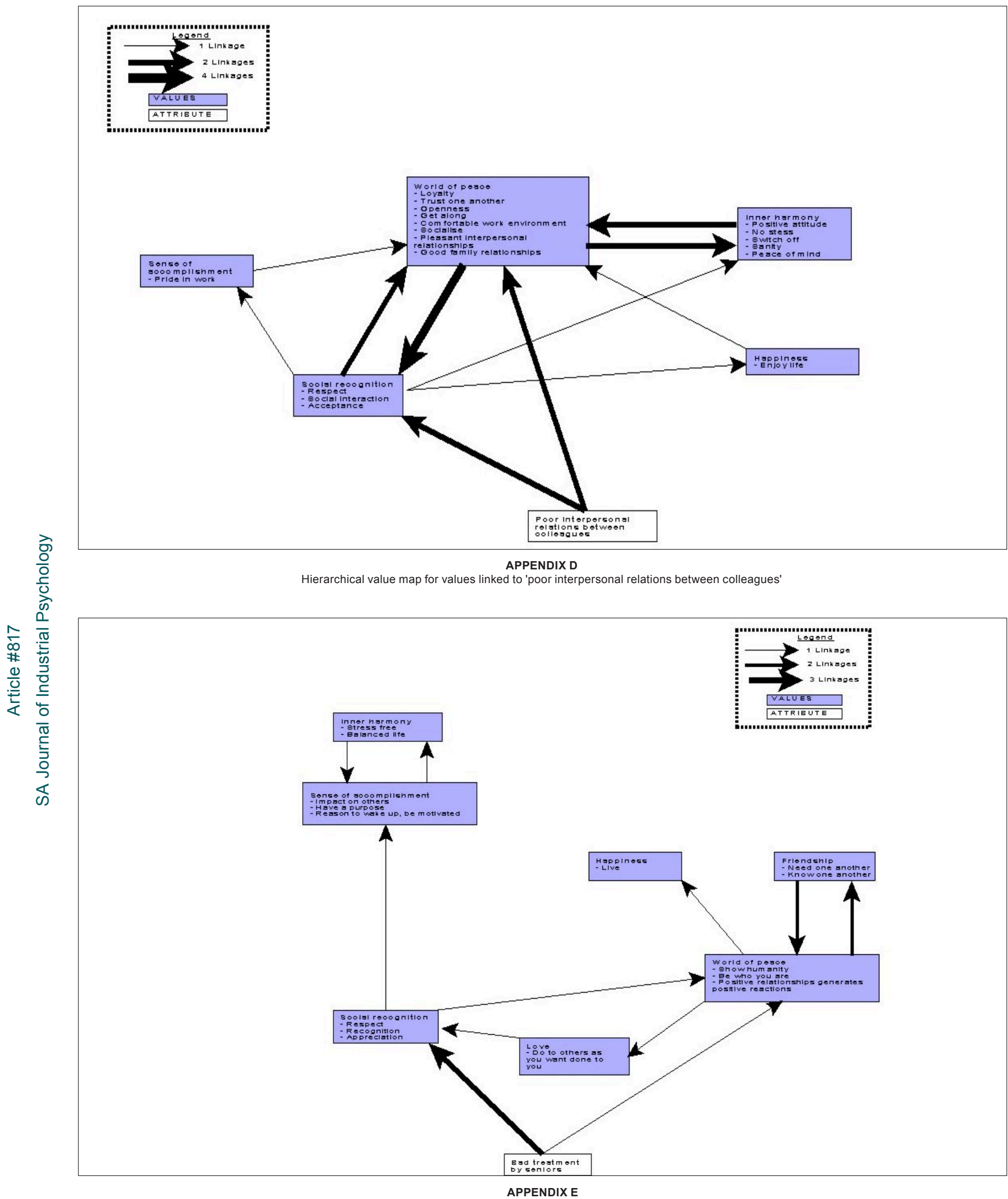

Hierarchical value map for values linked to 'bad treatment by seniors' 